\title{
HABITAT RAFFLESIA (Rafflesia zollingerianaKds.) DI BLOK KRECEK RESORT BANDEALIT TAMAN NASIONAL MERU BETIRI JAWA TIMUR
}

\author{
Indra Laksana1 ${ }^{1}$ Amir Syarifuddin', Nirmala Ayu Aryanti ${ }^{1}$ \\ ${ }^{1}$ Jurusan Kehutanan Fakultas Pertanian-Peternakan Universitas Muhammadiyah Malang \\ Email: indralaksana27@gmail.com
}

RANGKUMAN

Rafflesia zollingeriana Kds. merupakan bunga langka yang mempunyai ukuran diameter $35-45 \mathrm{~cm}$ dan termasuk bunga yang dilindungi oleh negara. $R$. zollingeriana Kds. di Indonesia dapat ditemui di Taman Nasional Meru Betiri, Jawa Timur yang memang memiliki keanekaragaman vegetasi yang melimpah. Penelitian ini bertujuan untuk mengidentfikasi persebaran dan habitat $R$. zollingeriana Kds., serta asosiasi antara $R$. zollingeriana Kds. dengan spesies lain yang ada di plot permanen Blok Krecek Resort Bandealit Taman Nasional Meru Betiri. Persebaran dan habitat $R$. zollingeriana Kds.dikaji melalui analisis vegetasi dengan menghitung Indeks Nilai Penting (INP), Indeks Kesamaan, Indeks Keragaman, Indeks Kekayaan, dan Indeks Kemerataan, serta melakukan analisis terhadap kondisi abiotik yang meliputi jenis tanah, kelembaban tanah, kelerengan, ketebalan seresah, dan $\mathrm{pH}$ tanah. Asosiasi antara $R$. zollingeriana Kds. dengan spesies lain dikaji melalui analisis kontingensi, uji chi square $\left(\mathrm{x}^{2}\right)$, dan uji tingkat kekuatan asosiasi. Tercatat sebanyak 4 individu $R$. zollingeriana Kds. yang mengelompok pada plot 1 . Habitat biotik $R$. zollingeriana Kds. adalah hutan hujan tropis yang tumbuh pada bagian akar dan batang inang Tegtrastigma sp, dengan spesies dominansinya bendo (Artocarpus elasticus Reinw. Bl dan jerukan (Polyalthia ruphii L.) sebanyak 48 individu. Asosiasi antara $R$. zollingeriana Kds. dengan vegetasi lain pada umumnya memiliki asosiasi positif, namun dari keseluruhan spesies yang telah ditemukan, asosiasi maksimum terjadi pada $R$. zollingeriana Kds. dengan sriwil kutil (Sterculia campanulata Jw.) dan bindung (Tetrameles mudiflora Gott.).

Kata Kunci:Rafflesia, Persebaran, Habitat, Asosiasi

ABSTRAK

Rafflesia zollingeriana Kds. is a rare flower that has a diameter of $35-45 \mathrm{~cm}$ and includes flowers protected by the state. R. zollingeriana Kds. in Indonesia it can be found in Meru Betiri National Park, East Java, which does have an abundant diversity of vegetation. This study aims to identify the distribution and habitat of R. zollingeriana Kds., And the association between R. zollingeriana Kds. with other species in the permanent plot of Blok Krecek Resort Bandealit Meru Betiri National Park. Distribution and habitat R. zollingeriana Kds. All analyzes of vegetation calculate the Index of Importance (INP), Similarity Index, Diversity Index, Wealth Index, and Equity Index, as well as analyzing the conditions of antibiotics covering Afghanistan, soil capacity, slope, thickness, and soil pH. Association between R. zollingeriana Kds. with other species, all analyzes of contingency, chi square (x2) tests, and levels of strength association. Four individuals of R. zollingeriana Kds were recorded. which grouped on plots 1 . Biotic habitat R. zollingeriana Kds. is a tropical rain forest that grows on the roots and host stem of Tegtrastigma sp, with its dominance species Bendo (Artocarpus elasticus Reinw. Bl and jerukan (Polyalthia ruphii L.) as many as 48 individuals. The association between R. zollingeriana Kds and other vegetation generally has positive association, but of all species that have been found, the maximum association occurs in R. zollingeriana Kds with sriwil warts (Sterculia campanulata Jw.) and bindung (Tetrameles mudiflora Gott.).

Keywords: Rafflesia, Persebaran, Habitat, Association 


\section{Pendahuluan}

Taman Nasional Meru Betiri merupakan kawasan konservasi yang memiliki potensi keanekaragaman flora dan fauna yang sangat tinggi. Taman nasional ini merupakan perwakilan dari tipe ekosistem hutan hujan tropika dataran rendah. Kawasan Taman Nasional Meru Betiri telah teridentifikasi flora sebanyak 518 jenis, terdiri 15 jenis yang dilindungi dan 503 jenis yang tidak dilindungi. Salah satu jenis tumbuhan yang dilindungi tersebut adalah Rafflesia zollingeriana Kds.

Rafflesia adalah tumbuhan yang unik karena ukuran bunganya yang besar, serta kehadirannya yang baru disadari ketika kuncup bunganya mekar. Rafflesia tersebar di Taman Nasional Meru Betiri Jawa Timur dengan populasi rafflesia yang umumnya kecil(Nais, 2001). Persebaran populasi dalam kawasan yang luas dan masa hidup yang pendek, mengakibatkan sulitnya pendataan secara berkelanjutan. Pendataan rafflesia secara inventore akan memudahkan pengambilan keputusan yang sesuai untuk kepentingan pelestarian rafflesia di Taman Nasional Meru Betiri, JawaTimur.

Kehadiran vegetasi pada suatu landscape akan memberikan dampak positif bagi keseimbangan ekosistem dalam kelestarian rafflesia. Rafflesia yang hidup di ekosistem hutan hujan tropis memang sangat membutuhkan kelembaban yang sangat tinggi yaitu 80-90\% (Zuhud, 1989). Komposisi vegetasi tersebut memang akan sangat membantu keseimbangan ekosistem untuk menunjang pertumbuhan rafflesia. Meskipun secara umum kehadiran vegetasi membeikan dampak positif bagi keseimbangan ekosistem, namun sering juga kehadiran vegetasi menimbulkan persaingan antar vegetasi.

Persaingan vegetasi pada suatu landscape sangat bervariasi, mulai dari persaingan untuk mendapatkan unsur hara, persaingan luas bidang dasar pada tapak, persaingan mendapatkan cahaya, dan lain-lain. Melihat berbagai dampak yang ditimbulkan oleh kehadiran vegetasi tersebut, khususnya pada kajian habitat rafflesia ini, studi analisis vegetasi sangat diperlukan untuk mengetahui komposisi vegetasi dan jenis apakah yang sangat mempengaruhi kehidupan dari rafflesia. Struktur dan komposisi vegetasi pada suatu landscape dipengaruhi oleh komponen ekosistem lainnya yang saling berinteraksi, sehingga vegetasi yang tumbuh secara alami (Setiadi, 1984).Oleh karenaitu, diperlukan penelitian mengenai habitat rafflesia yang terdapat di kawasan Taman Nasional Meru Betiri.

\section{BahandanMetode}

\section{LokasidanWaktuPenelitian}

Penelitian dilaksanakan padaJanuari 2017 selama kurun waktu satu bulan di Blok Krecek, Resort Bandealit, STPN Wilayah II, Balai Taman Nasional Meru Betiri. Secara administrasi, lokasi penelitian ini terletak diKecamatan Ambulu, Kabupaten Jember, Provinsi Jawa Timur Lokasi Penelitian dapat dilihat pada Gambar 1. 


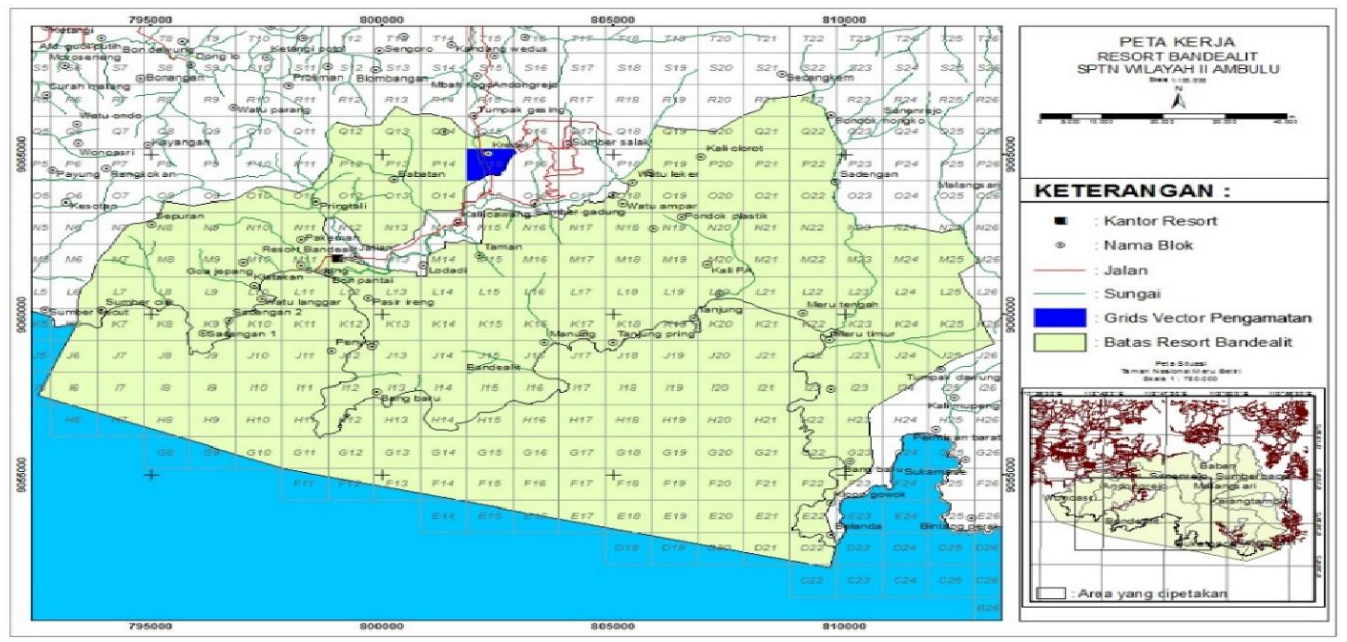

Gambar 1. PetaLokasiPenelitian

\section{MetodePengumpulan Data}

Metode pengambilan data yang digunakan untuk mengetahui persebaran $R$. zollingeriana Kds. Yaitu metode sensus, dengan cara penelusuran terhadap akar dan batang inang tetrastigma. Sedangkan untuk mengetahui kondisi habitat, digunakan metode sample plot, dengan ukuran plot 20 x 20 meter tanpa menggunakan intensitas sampling. Data yang diambil dalam plot meliputi 4 tingkat hidup pohon yaitu semai, pancang, tiang dan pohon. Parameter yang diukurantara lain jumlah individu per spesies; nama spesies (local dan ilmiah); serta tinggi dan diameter setinggi dada. Plot analisis vegetasi 20×20 meter dapat dilihat pada Gambar 2.

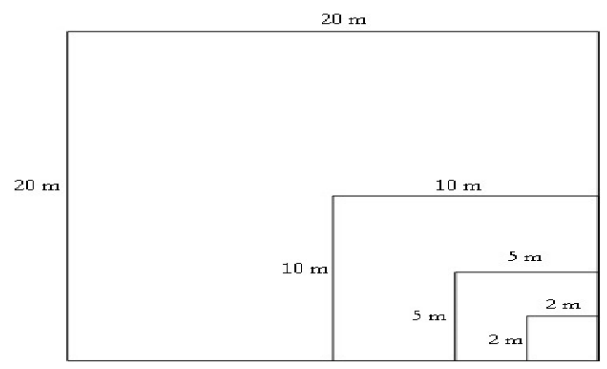

Gambar 2. Plot AnalisisVegetasi
Keterangan:

1) Petak ukur $2 \times 2 \mathrm{~m}$ untuk data semai (tinggi $<1,5 \mathrm{~m}$ )

2) Petak ukur $5 \times 5 \mathrm{~m}$ untuk data pancang (tinggi $1,5-3 \mathrm{~m}$ dan diameter $<15 \mathrm{~cm}$ )

3) Petak ukur $10 \times 10 \mathrm{~m}$ untuk data tiang (diameter $15-30 \mathrm{~cm}$ )

4) Petak ukur $20 \times 20 \mathrm{~m}$ untuk data pohon (diameter $>30 \mathrm{~cm}$ )

Data abiotic juga diperlukan dalam penelitian ini untuk mengetahui kondisi habitat ditinjau dari sisi abiotik. Data yang diambil yaitu data kondisi tanah antara lain data jenis tanah, kelembaban tanah, kelerengan, ketebalan seresah, dan $\mathrm{pH}$ tanah.

\section{Analisis Data}

a. AnalisisVegetasi

Analisis vegetasi dilakukan untuk mendeskripsikan persebaran dan kondisi habitat ditinjau dari sisi biotik. Selain itu, untuk mendeskripsikan kondisi habitat ditinjau dari sisi abiotic dilakukan dengan mendeskripsikan kondisi tanah di lokasi penelitian. Analisis vegetasi menggunakan perhitungan Indeks Nilai Penting (INP), Indeks Kesamaan, Indeks Keragaman, Indeks Kekayaan, dan Indeks Kemerataan.

- Kerapatan (batang/ ha) = Jumlah individu jenis ke-i Luas total petak contoh 


\section{- KerapatanRelatif $(\%)=$ \\ Kerapatan jenis ix 100\% \\ Kerapatan total \\ - Frekuensi $=$ \\ Frekuensi jenis i x 100\% \\ Frekuensi total \\ - FrekuensiRelatif $(\%)=$ \\ Jumlah petak contoh ditemukan jenis i \\ jumlah total petak contoh \\ - Dominansi $=$ \\ Luas bidang dasar (LBDS) jenis i \\ Luas petak contoh \\ - Dominansi Relatif $(\%)=$ \\ Dominansi jenis i x $100 \%$ \\ Dominansi total \\ - Indeks Nilai Penting = \\ $\mathrm{KR}+\mathrm{FR}+\mathrm{DR}$}

(Bismark, 2011)

Vegetasi yang berada di plot non rafflesia dan rafflesia dapat dihitung dengan menggunakan Indeks Kesamaan (Ludwig-Reynold).

$$
\frac{2 C}{A+B}
$$

Keterangan:

$\mathrm{C}=$ Jumlah spesies yang sama dan terdapat pada kedua komunitas

$A=$ Jumlah spesies di dalam plot rafflesia

$\mathrm{B}=$ Jumlah spesies di dalam plot non rafflesia

Keanekaragaman jenis ditentukan dengan rumus

Indeks Keanekaragaman Shannon-Wiener:

$$
H^{\prime}=\sum_{i=1}^{n}\left[\frac{\mathrm{ni}}{\mathrm{N}} \ln \frac{\mathrm{ni}}{\mathrm{N}}\right]
$$

$$
\begin{aligned}
& \mathrm{H}^{\prime}=\sum \text { pi In pi } \\
& \mathrm{Pi}=\frac{n !}{N}
\end{aligned}
$$

Keterangan:

H'= Indeks Keanekaragaman Shannon-Wiener

$\mathrm{ni}=$ jumlah individu jenis ke-n

$\mathrm{N}=$ total jumlah individu

Adapun nilai H' adalah sebagai berikut:

$\mathrm{H}^{\prime}<1$ = tingkat keanekaragaman jenis rendah
H'1-3 = tingkat keanekaragaman jenis sedang

$\mathrm{H}^{\prime}>3=$ tingkat keanekaragaman jenis tinggi

(Bismark, 2011).

Kekayaan jenis vegetasi ditentukan dengan menggunakan Indeks Kekayaan (LudwigReynold).

$$
\mathrm{R}=\frac{S-1}{\ln (N)}
$$

Keterangan:

$\mathrm{R}=$ Indeks Kekayaan Jenis

$\mathrm{S}=$ Jumlah Jenis

$\mathrm{N}=$ Jumlah Total Individu

Kemerataan jenis vegetasi ditentukan dengan menggunakan Indeks Kemerataan (LudwigReynold).

$$
\mathrm{E}=\begin{gathered}
H \prime \\
\ln (s)
\end{gathered}
$$

Keterangan:

$\mathrm{E}=$ Indeks Kemerataan Jenis

$\mathrm{H}^{\prime}=$ Indeks Keanekaragaman Jenis

$\mathrm{S}=$ Jumlah Jenis

(Prasetyo, 2016)

b. AnalisisAsosiasi

Analisis untuk mengetahui asosiasi antar spesies menurut Sugianto (1994), yaitu:

1) menentukan jenis-jenis vegetasi penyusun hutan yang mempunyai Indeks Nilai Penting 10\% atau lebih; dan

2) melakukan perhitungan untuk mengetahui adanya asosisasi antara jenis vegetasi dengan menggunakan tabel kontingensi $2 \mathrm{x}$ 2 meter, yaitu dimulai dengan jenis yang mempunyai Indeks Nilai Penting tertinggi. Selanjutnya hasil $\mathrm{N}$ dari tabel kontingensi 2 × 2 meter yang disajikanpadaTabel 1 dan dilakukan pengujian dengan menggunakan uji chi square $\left(\mathrm{x}^{2}\right)$. 
Tabel 1. TabelKontingensi $2 \times 2$ meter

\begin{tabular}{|c|c|c|c|}
\hline Spesies A & Ada & $\begin{array}{c}\text { Tidak } \\
\text { ada }\end{array}$ & Jumlah \\
\hline Ada & $a$ & $b$ & $m=a+b$ \\
\hline $\begin{array}{c}\text { Tidak } \\
\text { ada }\end{array}$ & $c$ & $d$ & $n=c+d$ \\
\hline Jumlah & $r=a+c$ & $s=b+d$ & $\begin{array}{c}N=a+b \\
+c+d\end{array}$ \\
\hline
\end{tabular}

Keterangan: (a: Plot keberadaan spesies A dan spesies B; b: Plot ketiadaan spesies A dan keberadaan spesies B; c: Plot keberadaan spesies A dan ketiadaan spesies B; d:

Plot ketiadaan spesies A dan ketiadaan spesies B)

Analisis terhadap asosiasi juga dilakukan berdasarkan ukuran kekuatan dengan menghitung Indeks Ochial, Indeks Dice, dan Indeks Jaccard. Menurut Indriyanto (2006), dari ketiga indeks tersebut cenderung bernilai 0 saat tidak ada asosiasi dan bernilai 1 saat asosiasi maksimum.

- Indeks Ochiai (OI)

Indeks ochiai (OI) dijelaskan dalam rata-rata geometrik $\mathrm{a} / \mathrm{m}$ dan $\mathrm{a} / \mathrm{r}$ yaitu:

$$
\frac{a}{\sqrt{a+b \sqrt{a+c}}}
$$

\section{- Indeks Dice (DI)}

Indek dice (DI) dijelaskan dalam rata-rata

keseimbangan $\mathrm{a} / \mathrm{m}$ dan $\mathrm{a} / \mathrm{r}$ yaitu:

$$
\begin{gathered}
2 a \\
2 a+b+c
\end{gathered}
$$

-Indeks Jaccard (JI)

Indeks Jaccard (JI) adalah proporsi nilai dari plot, dimana spesies muncul sebagai nilai total dari plot saat salah satu dari jenis sesies ditentukan:

$$
\frac{a}{2 a+b+c}
$$

Jika nilai indeks mendekati angka 1 maka hal tersebut menunjukkan bahwa hubungan antara kedua spesies tumbuhan tersebut semakin kuat.

\section{Hasil dan Diskusi}

Persebaran dan Habitat Rafflesia zollingeriana Kds.

Hasil pengamatan di plot permanen rafflesia Blok Krecek, Resort Bandealit, Taman Nasional Meru Betiri diperoleh 4 individu $R$. zollingeriana Kds. dengan kondisiyakni, 3 individu knop segar dan 1 individu mekar mati. Rafflesia yang ditemukan hanya mengelompok pada plot I, dimana menandakan bahwa persebaran rafflesia yang ditemukan tidak merata pada seluruh plot karena hanya berada dalam satu plot saja.Menurut Lestari (2013), rendahnya populasi dan kematian bunga rafflesia disebabkan oleh dua hal yaitu tergantungya distribusi nutrisi dari inang kepada knop rafflesia dan adanya gangguan dari satwa liar atau manusia. Zuhud (1988) juga menyebutkan bahwa kematian bunga rafflesia disebabkan oleh ancaman manusia yang memungut knop untuk dijadikan bahan baku jamu. Persebaran rafflesia dapat dilihat pada

\section{Gambar 3.}




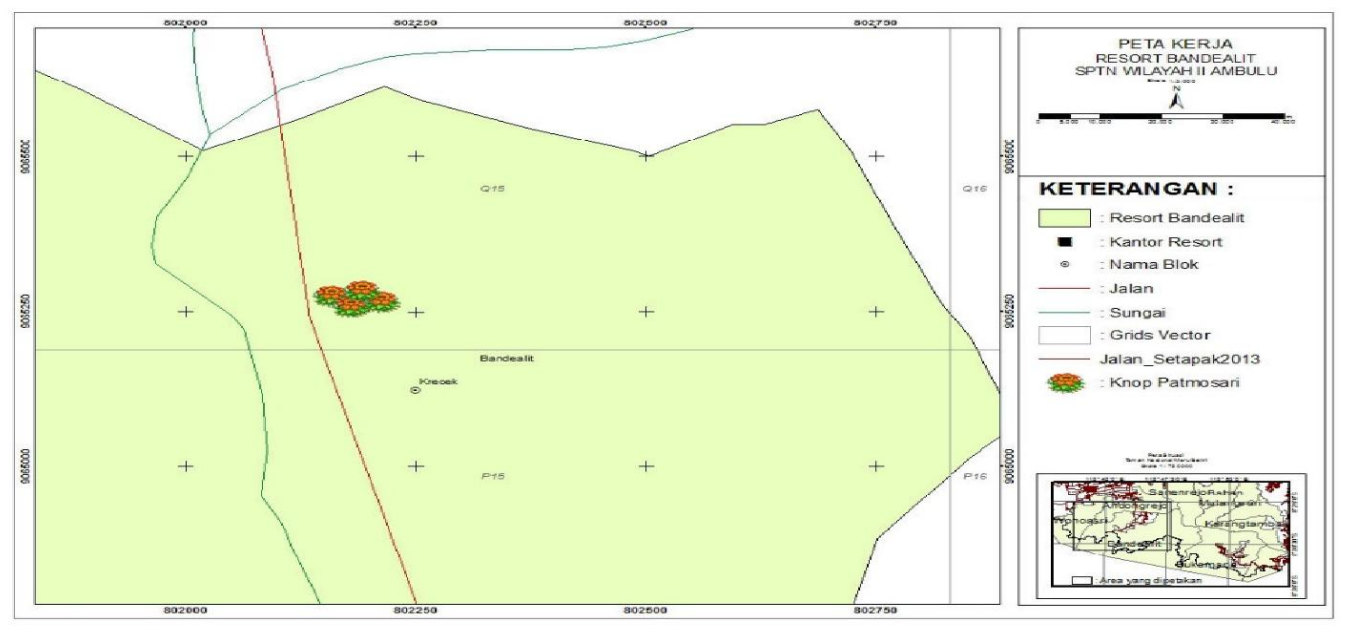

Gambar 3. Peta Persebaran R. zollingeriana.Kds di Plot Permanen

Karakteristik habitat rafflesia dapat ditinjau dari kondisi komponen biotik dan abiotik. Kondisi komponen biotik meliputi kondisi inang dan kondisi vegetasi. Inang dari rafflesiaya itu tetrastigma. Tetrastigma termasuk tumbuhan berbiji yang melakukan perkembang biakan secara generatif menggunakan biji. Namun, pada plot pengamatan ditemukan tetrastigma tumbuh secara vegetatif. Hasil pengamatan menunjukkan bahwa hanya ada 2 individu inang tetrastigma yang ditumbuhi oleh rafflesia.Tumbuhan yang dipanjati oleh tetrastigma pada plot pengamatan merupakan pohon yang bertajuk tinggi sehingga memberikan kesempatan bagi tetrastigma untuk memperoleh cahaya untuk keberlangsungan hidupnya. Selain kondisi inang, kelangsungan hidup rafflesia juga dipengaruhi oleh kondisi vegetasi di sekitarnya. Hasil pengamatan terkait kondisi vegetasi menunjukkan bahwa jumlah spesies tertinggi adalah jerukan (Polyalthiaruphii L.) dengan jumlah individu sebanyak 48 individu, sedangkan spesies terendah adalah suren (Tonnasureni B1. Merill.) dengan jumlah individu 1 individu saja. Jumlah individu keseluruhan sebanyak 385 individu yang tersebar merata di setiap petak ukur. Berikut grafik terkait jumlah individu dari setiap spesies yang ditemukan disajikan pada Gambar 4.

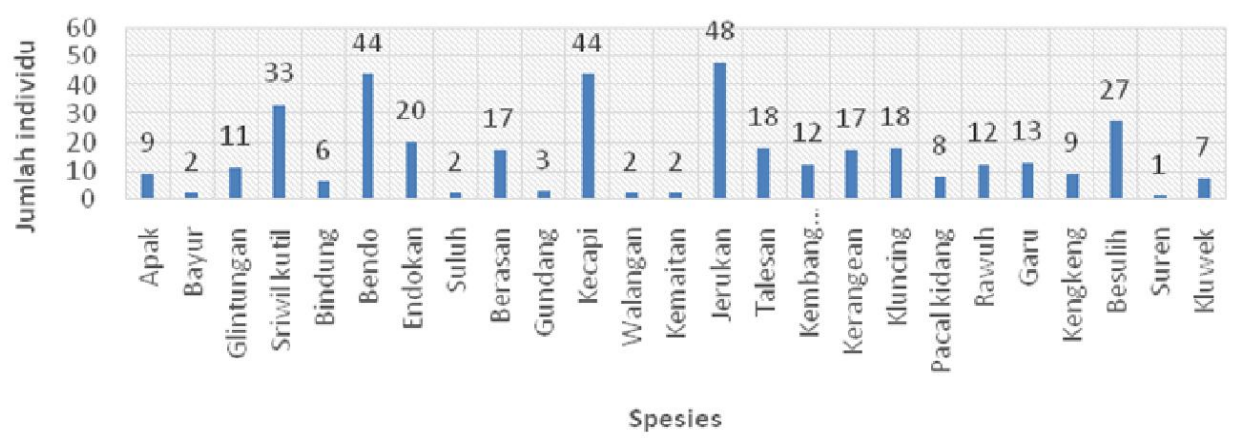

Gambar 4. Grafik Jumlah Individu Setiap Spesies di Lokasi Pengamatan

Berdasarkan hasil perhitungan Indeks Nilai Penting menunjukkan penurunan dari tingkat semai menuju pohon. Hal ini dikarenakan adanya persaingan antar maupun sesama jenis individu. Persaingan atau kompetisi ini disebabkan jenis-jenis tersebut mempunyai kebutuhan hidup yang sama akan unsur 
hara, sedangkan sumber-sumber yang mendukung Indeks Nilai Penting spesies disajikan pada kebutuhan hidup itu sendiri terbatas. Berikut grafik

Gambar 5.

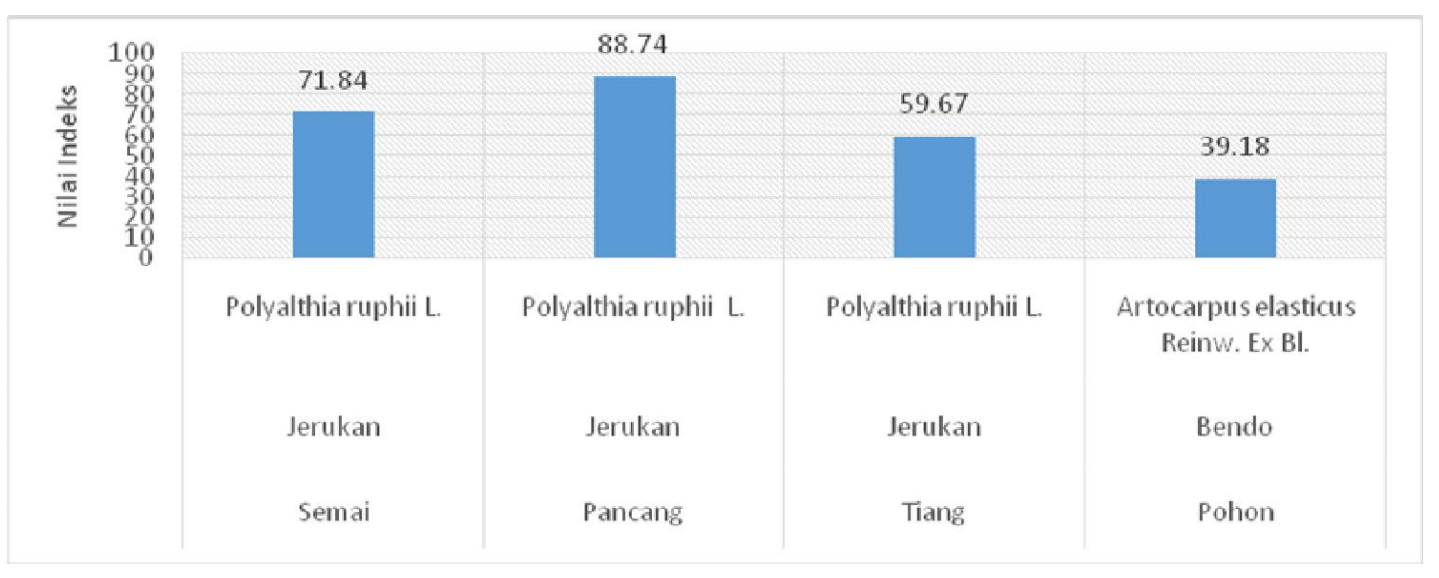

Gambar 5. Indeks Nilai Penting Spesies Tertinggi

Selain Indeks Nilai Penting, kondisi habitat juga ditinjau dari keragaman, kekayaan, kemerataan, dankesamaan spesies. Jenis dan jumlah spesies yang ada di plot permanen rafflesia Blok Krecek cukup tinggi. Adapun nilai keragaman menunjukkan bahwa tingkat keragaman di plot permanen rafflesia blok Krecek masih tergolong sedang karena nilai indeks keragaman tidak mencapai nilai 3 atau lebih.Keragaman suatu komunitas juga dilihat dari penyebaran spesies dalam komunitas tersebut yang dinyatakan dalam indeks kemerataan (Ludwig, 1988). Apabila nilai indeks mendekati 0 maka spesies dalam suatu komunitas tidak tersebar merata, sebaliknya apabila nilai indeks mendekati 1 maka spesies dalam suatu komunitas tersebar merata. Kemerataan pada plot permanen rafflesia Blok Krecek termasuk tidak terlalu merata karena nilai indeks kemerataannya tidak mencapai 1. Berdasarkan keseluruhan indeks, menunjukkan bahwa habitat vegetasi pada plot permanen rafflesia Blok Krecek cukup baik, yakni dari 12 plot yang telah dibuat, rafflesia hanya ditemukan pada 1 plot saja, dengan demikian plot tersebut dapat dibagi menjadi 2 tipe, yaitu plot rafflesia (plot ditemukannya rafflesia) dan plot non rafflesia (plot tidak ditemukannya rafflesia). Persamaan komposisi spesies pada kedua tipe plot tersebut dapat dilihatdengancara menghitung indeks kesamaan.Perbedaan komposisi spesies antara plot rafflesia dan non rafflesia sangat jelas berbeda, khususnya pada tingkat pertumbuhan anakan pohon (semai dan pancang) yang memiliki nilai lebih rendah dari pada pada tingkat pertumbuhan tiang dan pohon. Hal ini selaras dengan hasil penelitian Ali (2014) yang menunjukkan bahwa indeks kesamaan komposisi spesies rafflesia menunjukkan nilai indeks yang rendah pada tingkat pertumbuhan anakan pohon (semai dan pancang) dan menunjukkan nilai indek tinggi pada tingkat pertumbuhan tiang dan pohon. Persaingan antara tumbuhan bawah dan anakan pohon untuk memperoleh zat-zat organik dan anorganik di dalam tanah mengakibatkan rendahnya nilai indeks pada tingkat pertumbuhan anakan pohon. Nilai Indeks Keragaman, Kekayaan, Kemerataan, dan Kesamaan disajikan pada Gambar 6. 


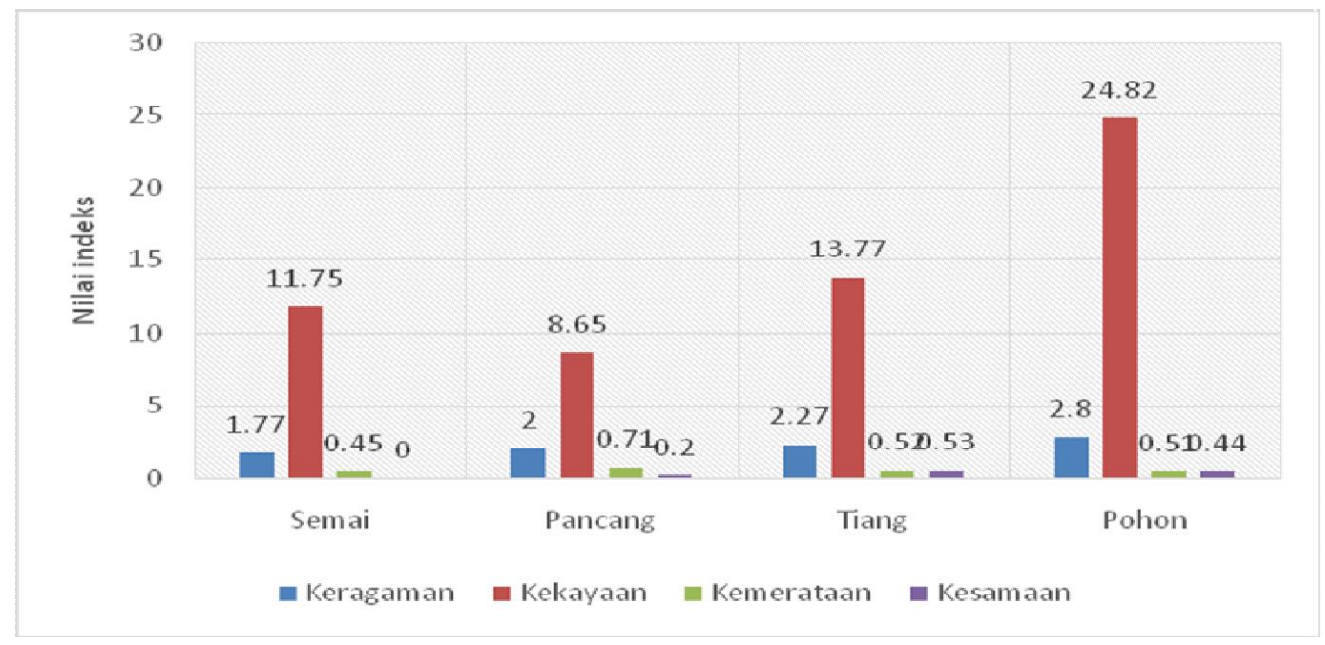

Gambar 6. Nilai Indeks Keragaman, Kekayaan, Kemerataan, dan KesamaanVegetasi

Kondisi habitat ditinjau dari komponen abiotik, menunjukkan bahwa jenis tanah yang ada di plot permanen rafflesia Blok Krecek termasuk tanah latosol yang pada umumnya memiliki warna merah hingga gelap, teksturnya lempung dan memiliki horizon. Lapisan horizon yang dimiliki oleh tanah latosol cenderung tebal namun demikian batas horizon tanah latosol tidak terlihat begitu jelas. Kelembaban tanah cukup tinggi yaitu $86,67 \%$, hal ini diasumsikan dipengaruhi oleh curah hujan yang cukup tinggi pada Januari 2017.Adapun rata-rata penutupan seresahyaitu 7,92 cm, juga dapat mempengaruhi kelembaban tanah dengan cara menahan lapisan tanah untuk melakukan pengguapan, sehingga kelembaban tanah tinggi. Kelerengan 80\%, padalokasipenelitian menunjukkan bahwa memang plot permanen rafflesia memiliki lahan yang cukup curam, sedangkan untuk $\mathrm{pH}$ tanah dapat dikatakan netral karena dari keseluruhan atau rata-rata $\mathrm{pH}$ mendekati 7.Kawasan Taman Nasional Meru Betiri memiliki curah hujan tinggi yang ditandai dengan tampilan hijau muda atau sekitar 301 - $400 \mathrm{~mm}$ pada Januari 2017. Melihat dari prakiraan curah hujan bulanan tersebut dan apabila dijadikan prakiraan curah hujan tahunan maka menjadi 1806 - 2400 $\mathrm{mm} /$ tahun. Menurut Zuhud (1998) curah hujan rata-rata tahunan untuk spesies $R$. zollingeriana
Kds. adalah 1867 - 2397 mm/tahun. Hal ini menjukkan bahwa kawasan Taman Nasional Meru Betiri merupakan tempat tumbuh yang sesuai untuk rafflesia.

Asosiasi Rafflesia zollingeriana Kds.

Interaksi yang terjadi diantara jenis dipengaruhi oleh faktor kerapatan dan frekuensi yang tinggi, sehinggamenghasilkanasosiasi yang positif (Deshmukh, 1992). Asosiasi negatif tidak menunjukkan adanya toleransi untuk hidup bersama pada area yang sama atau dapat dikatakan tidak ada hubungan timbal balik yang saling menguntungkan khususnya dalam pembagian ruang hidup (Muller, 1974). Kerapatan dan frekuensi yang cukup tinggi di dalam suatu populasi akan menimbulkan adanya tarik menarik antara jenis dalam rangka memanfaatkan lingkungan yang ada untuk menciptakan kondisi kondisi hidup yang stabil. Kondisi ini memberi pengertian bahwa interaksi yang terjadi secara alami, dapat bertahan untuk jangka waktu yang panjang selama komunitas tersebut berada dalam keadaan seimbang. Pernyataan ini sangat mendukung kondisi vegetasi di plot permanen rafflesia Blok Krecek, sebab berdasarkan data analisis vegetasi seperti kerapatan dan 
frekuensi, sangat menunjang untuk terjadinya interaksi positif antara spesies-spesies yang ada. Berdasarkan hasil analisis, bahwa asosiasi yang terjadi pada rafflesia dengan spesies lain di plot rafflesia Blok Krecek pada umumnya adalah positif. Tercatat ada 9 macam spesies yang memiliki asosiasi positif dengan rafflesia. Spesies yang berasosiasi positif dengan B1.); dan kecapi (Sondoricum koetjapie Mal.). Hal ini dapat dikatakan bahwa plot permanen rafflesia Blok Krecek mempunyai kompleksitas ekologi yang tinggi dengan beberapa jenis yang berasosiasi positif dengan rafflesia. Asosiasi antar spesies ini juga dinyatakan dalam tingkat kekuatan asosiasi. Berdasarkan hasil uji indeks ochiai, dice dan jaccard antara rafflesia dengan spesies lain menunjukkan adanya variasi data, hal ini ditandai dengan derajat indeks yang berbeda-beda. Tercatat 2 spesies yaitu sriwil kutil (Sterculia campanulata Jw.) dan bindung (Tetrameles mudiflora Gott.) pada tingkat pertumbuhan pancang mendapatkan derajat indeks yang maksimal dengan nilai 1. Hal ini dapat diasumskan dari 9 macam spesies yang memiliki asosiasi positif dengan rafflesia, hanya ada 2 spesies yang memiliki asosiasi positif maksimal yaitu sriwil kutil (Sterculia campanulata Jw.) dan bindung (Tetrameles mudiflora Gott.), selain spesies tersebut tetap memiliki asosiasi positif, akan tetapi asosiasinya tidak maksimal.

\section{Kesimpulan}

Tercatat sebanyak 4 individu Rafflesia zollingeriana Kds. dengan kondisi yakni 3 individu knop segar dan 1 individu mati, yang hidup secara mengelompok pada plot 1. Habitat biotik R. zollingeriana Kds. Yaitu tumbuh pada rafflesia tersebut antara lain sriwi lkutil (SterculiacompanulataJw.); bindung (Tetrameles mudiflora Gott.); berasan (Drypetesovalis L.); endokan (Xantho phylum vitellinum BI. Dietr.); jerukan (Polyalthiar uphii L.); talesan (Perseaodoratis Kosterm.); apak (Ficus benjamina L.); bendo (Artocar puse lasticus Reinw.

akar dan batang Tegtrastigma $\mathrm{sp}$, dengan spesies dominansinya bendo (Artocarpus elasticus Reinw. Bl.) dan jerukan (Polyalthiaruphii L.). Habitat abiotiknya dicirikan pada ketinggian 1-170 meter di atas permukaan laut, kelerengan curam, dan tumbuh pada iklim C. Asosisi antara R. zollingeriana Kds. dengan vegetasi lain pada umumnya memiliki asosiasi positif, namun dari keseluruhan spesies yang telah ditemukan, asosiasi maksimum terjadi antara $\mathrm{R}$. zollingeriana Kds. dengan sriwil kutil (Sterculia campanulata Jw.) bindung (Tetrameles mudiflora Gott.).

\section{Saran}

Perlu dilakukan pemetaan persebaran Rafflesia zollingeriana Kds. terbaru di Taman Nasional Meru Betiri beserta inventarisasi inang tetrastigma secara teratur, untuk menentukan waktu mekar bunga $R$. zollingeriana Kds., sehingga dapat memberikan nilai tambah dalam aspek konservasi.

\section{DaftarPustaka}

Ali, M. 2014. Karakteristik Habitat Raffleisa (Rafflesia patma Blume.) di Cagar Alam Bojonglarang Jayanti Cianjur Jawa Barat. Bogor: Institut Pertanian Bogor.

Bismark, M. 2011. ProsedurPerasiStandar (SOP)

Untuk

Survey 
KeragamanJenisPadaKawasanKonservasi.

KementerianKehutanandan ITTO. Bogor.

Lestari, D. 2013. Konservasi Rafflesia zollingeriana. Kds di Taman Nasional Meru Betiri. Bogor: Institut Pertanian Bogor.

Ludwig, R. 1988. Statistical Ecology. Canada: A Primer on Methods and Computing.

Muller. 1974. Aims and Method of Vegetation Ecology. New York: Wiley International Edition.

Prasetyo, F. 2016. Petunjuk Prektek Pengelolaan Hutan Tanaman. Yogyakarta: Fakultas Kuhutanan Universitas Gajah Mada.
Setiadi. 1984. Ekologi Tropika. Bandung: Institut Teknologi Bandung.

Sugianto, A. 1994. Ekologi Kuantitatif. Surabaya: Usaha Nasional.

Zuhud. 1989. Ecologic Study of Rafflesia

zollingeriana Kds in Meru Betiri National

Park. Bogor: Bogor Agricultural University.

Zuhud. 1998. Rafflesia Indonesia Keanekaragaman, Ekologi dan Pelestariannya. Bogor: Yayasan Pembina Swaka Alam dan Margasatwa Indonesia. 